\title{
Statistical sources and African postcolonial economic history: notes from the (digital) $\operatorname{archives}^{1}$
}

\author{
Rebecca Simson, Oxford University, Wadham College
}

\section{Introduction}

African economic history is in ascendance. After a hiatus from the 1980's to the early 2000's, the discipline is undergoing a renaissance marked by a rise in publications and its growing integration into global economic history debates (Broadberry and Austin, 2014; Gardner and Fourie, 2014; Fourie 2019). Yet this African economic history resurgence suffers from a missing middle. While the colonial period is comparatively well documented by economic historians, the postcolonial era commonly features as an outcome of past conditions rather than a period of study in its own right. Many of the rich comparative studies of state development and living standards across African colonies produced in recent years end their data series in the early 1960's when statistical collection by the colonial metropoles ceased.

This note discusses some of the reasons for this lacuna in the African economic history literature, focusing on the changing nature of statistical publications after independence. It provides guidance, based on the author's own experience, which may help researchers interested in the postcolonial era to locate comparatively underutilized economic statistics covering the 1960's to the present.

\section{'The compression of history'}

African economic history came of age in the 1960's and 1970's as decolonisation spurred scholars to engage with the continent's precolonial and colonial material past and chart how African economies were modernizing and transforming (see Hopkins, 2019, for an overview). By the late 1980's, however, the discipline lost influence, partly due to a decline in economic history writing generally, spurred by the epistemological and methodological divergence between the economics and history disciplines. But African economic history was particularly hard hit, as the economic crises affecting much of the African continent in this period reduced international interest in the region's economic past. As Africa's economic fortunes rebounded in the 2000's, African economic history writing has flourished once more, marked by a growing research output, new academic networks dedicated to the subdiscipline and greater integration into global economic history debates.

\footnotetext{
${ }^{1}$ The author would like to thank Leigh Gardner, Alfonso Herranz-Loncan and the two anonymous peer reviewers for their helpful comments and suggestions on earlier versions of this note.
} 
One of the catalysts of this revived interest in African economic history was the bold theses and methods for studying long-term development pioneered by Acemoglu, Johnson and Robinson (see discussion in Hopkins, 2009). Drawing on new institutional economics, their work used regression analysis and instrumental variables to demonstrate causal relationships between historical events or institutional structures and contemporary economic outcomes. Their now-famous 'reversal of fortune' thesis, which argued that more densely populated regions were less likely to be settled under colonialism and were instead subjected to 'extractive institutions' that hindered long-term development, served as inspiration for a plethora of similar studies seeking to understand the historical roots of underdevelopment in Africa specifically (Acemoglu, Johnson and Robinson, 2002). Prominent examples include Nathan Nunn's (2008) research which demonstrated a negative effect of the intensity of the slave trade on a country's current level of income, Nunn and Wantchekon's paper linking slave trade intensity with contemporary levels of mistrust (2011), and Michalopoulos and Papaioannou's research linking pre-colonial state centralisation to contemporary levels of development (2013). These research methods has been applied prolifically to African topics. In a review of economic history 'persistence' papers that identify causal relationships between an event in the past and a contemporary outcome, Giovanni Federico found that 23 out of the 69 persistence papers published since 2000 were on African history, the biggest regional cluster (Federico, 2017). Most examined the effect of events more than a century before the contemporary outcome it was shown to influence. Fourie and Obikili (2019) refer to this as small T, large N studies, which furnish only a few observations across time, but across a large set of countries or regions.

This methodological approach has been criticised for its 'compression of history', as the methods used shed little light on the reasons for institutional persistence or how said institutions evolved between the two periods in from which dependent and explanatory variables are drawn (Austin, 2008; Jerven, 2015). Moreover, closer data scrutiny and efforts to replicate some of the earlier of these studies have thrown doubt on the data quality and statistical robustness of many papers of this genre. Jerven (2013) has criticized the quality of the commonly used dependent variable in these studies (GDP per capita), showing that country rankings within Africa are unreliable and unstable. This point was also demonstrated by Frankema and van Waijenburg in a replication exercise which showed that results from one prominent study changed when they varied the outcome year for which GDP per capita was taken. Cogneau and Dupraz (2014) similarly conducted a replication exercise that demonstrated how a given set of results were driven by systematic biases in the measurement of population density based on satellite luminosity data. In another case endogenous measurement error and omitted variable bias were found to undermine the reliability of explanatory variables, in this case mission location (Jedwab, Meier zu Selhausen and Moradi, 2019). Similarly, Cogneau and Dupraz (2015) have illustrated the problems of using Murdock's ethnographic atlas as a measure of pre-colonial institutional variation. Others have pointed to common statistical weaknesses in persistence studies, 
such as spatial autocorrelation of residuals (Kelly, 2019). Austin (2008) and Lamoreaux (2015) have called for more detailed case study work that fills the gap between historical event and contemporary outcome and explains processes of change over time. Such approaches would strengthen our understanding of causal paths and institutional persistence or lack thereof, and guard against spurious results.

Other strands of recent economic history research have indeed focused on changing living standards and demographics in Africa, tracing change over time for a smaller set of countries. Frankema and van Waijenburg (2012) reconstructed real wages across a set of British colonies in Africa over the colonial period to examine changes in living standards over time. Several studies have looked in depth at the fiscal evolution of the colonial state (Gardner, 2012; Frankema and van Waijenburg, 2014; Cogneau et al., 2015). But partly because of the move towards greater quantification in economic history and thus greater demands for data, this type of research has focused heavily on the colonial period, drawing primarily on administrative data collected by the colonial state (Hopkins, 2019; Fourie, 2016). The British and French empires collected broadly the same types of statistics across each of their colonies, archived in central repositories, which has made the digitization of these sources relatively cost effective, and enables comparison across time and space.

Many of these studies therefore end their analysis in the 1960's, when data collection fell to individual national statistical agencies. Consequently, the African economic history upsurge has been heavily skewed towards studies of the colonial era (roughly 1890's-1960), while the pre- and postcolonial periods remain comparatively understudied. Of the 48 working papers ${ }^{2}$ published by the Africa Economic History Network since its foundation in 2012, for instance, nine include coverage of the pre-colonial period, 39 cover the colonial period, and 13 include some coverage of the postcolonial period. Of these 13 , however, eight of the paper with postcolonial coverage are birds-eye papers that present new long-run time series data covering a century or more and lack an explicit focus on economic change in the postcolonial era (Moradi, Austin and Baten, 2012; Frankema and Jerven,

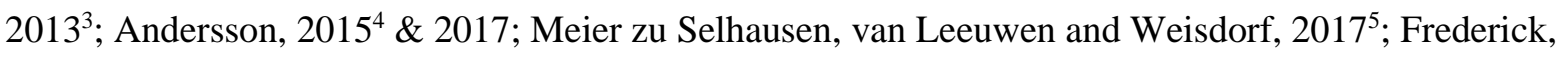
2018; von Fintel and Fourie, 20196 ). Two papers relate colonial era phenomenon to contemporary educational outcomes (Cogneau and Moradi, 20127; Juif, 2019). Only three examine economic events of the postcolonial era specifically: Emmanuel Akyeampong's discussion of African socialism, ${ }^{8}$

\footnotetext{
${ }^{2}$ Up until August 2019, and excluding the inaugural paper which offers a historiography and literature survey.

${ }^{3}$ Later published in the Economic History Review (Frankema and Jerven, 2014).

${ }^{4}$ Later published in Economic History of Developing Regions (Andersson, 2017).

${ }^{5}$ Later published in the Economic History Review (Meier zu Selhausen, van Leeuwen and Weisdorf, 2018).

${ }^{6}$ Later published in the Journal of Comparative Economics (Von Fintel, D. and Fourie, J. 2019).

${ }^{7}$ Later published in the Journal of Economic History (Cogneau and Moradi, 2014).

${ }^{8}$ Later published in Economic History of Developing Regions (Akyeampong, 2018).
} 
Gareth Austin's forward-looking think piece on 'late development' in Africa, and Simson's paper on the composition of public sector employment in the postcolonial era.

Coverage in the Economic History of Development Regions is similar. Since 2010, when the journal expanded its focus to developing regions, it has published 57 articles on African topics (excluding historiographical or theory pieces). Of these, 38 are on South Africa and focus primarily on the colonial or Apartheid eras or financial history topics. Of the 19 articles on the rest of the continent, four take a long-term perspective that spans the postcolonial, colonial and in some cases pre-colonial period, while only two explore events specific to the postcolonial era.

To be fair, a limited focus on the latter $20^{\text {th }}$ century is not unique to African economic history. Contemporary history has until recently occupied a precarious position in most history departments. Prior to the 1960s, history explicitly focused on periods outside living memory, on the grounds that contemporary history cannot be studied dispassionately (Brivati, 1996). General economic history journals, with a global scope, tend to contain a comparatively small share of articles on the post1960's era, although the periods coverage are considerably broader than in the African sub-field, and much less focused on the $20^{\text {th }}$ century overall. But in comparison with general African history writing, the omission of the postcolonial period is more marked in the economic history field. In the Journal of African History, by comparison, over a third of research articles published in the past two years pertained to the postcolonial period. ${ }^{9}$

Furthermore, the study of postcolonial African economic history seems particularly salient given that so much recent African economic history writing is motivated by a desire to understand why African countries lag behind other regions of the world economically today (Akyeampong et al., 2014). While a growing literature has sought to identify the historical origins of underdevelopment, much fewer engage in detail with events of the postcolonial period, when African governments ought to have had the greatest possibility of altering these legacies, and the number of independent governments ought to have spurred the greatest plethora of development paths.

Consequently, many important recent economic ruptures that have influenced development paths, from the terms of trade shocks of the 1970's, economic crises of the 1980's, structural adjustment reforms of the 1990's, to deindustrialisation and later recovery in the 2000's, have received comparatively little attention from economic historians. These topics are studied by economists and political scientists, some with a strong understanding of the continent's economic history no doubt, but who are not aiming to explain these processes of economic change using the economic historian's frameworks and toolkits, or to explicitly place them in historical context. Many of these economic

\footnotetext{
${ }^{9}$ In total there were 10 articles with a postcolonial focus, 16 with a colonial focus, and 5 with a pre-colonial focus; but of these, three spanned more than one era; two articles excluded from count as they focused on historiography rather than history per se.
} 
studies compare sub-Saharan Africa's unfavourable development performance to other parts of the world, but do less to show whether and when these performance gaps emerged. Understanding whether, why and when politically independent countries broke or attempted to break with economic legacies of the colonial era, and how external factors conditioned country paths, is crucial to this knowledge project and requires us to take the postcolonial economic policy and contexts seriously.

\section{Underutilized statistical sources}

A major reason for this lacuna is that the sources of economic statistics available to researchers changed in form and function after independence. In the 1960's and 1970's statistical collection fell to dozens of separate national statistical offices, with new interests, new lines of accountability and different levels of technical capability. With the onset of the fiscal crises of the 1970's and 1980's, these statistical bureaus, like most government agencies, faced serious funding constraints. Consequently, postcolonial African economic data is harder to collect, patchier and of more varied quality (see Jerven, 2013). Given the importance placed on quantification and 'big data' to contemporary economic history writing (Fourie, 2016), this has naturally pushed researchers towards topics and periods where the quantitative evidence is richest.

However, while recognizing these considerable constraints, the data deficit may not be quite as tragic as sometimes portrayed (see Devarajan, 2013, 'Africa's statistical tragedy'). By looking at a broader range of postcolonial sources and investing time in understanding how statistics collection changed in a given country after independence, progress can be made. Below I discuss several sources of economic data for postcolonial African countries, organised by source or repository, which offer possibilities for the construction of time series data of common economic variables. This list builds on the authors own research experience and is not exhaustive. It seeks merely to provide some possible starting points for researchers interested in quantitative analysis Sub-Saharan Africa's recent past. ${ }^{10}$

Table 1. Sources of postcolonial African economic and social data

\begin{tabular}{|c|c|c|c|c|}
\hline $\begin{array}{l}\text { Source or } \\
\text { repository }\end{array}$ & $\begin{array}{l}\text { Typical publications } \\
\text { titles }\end{array}$ & Statistical topics & Location & $\begin{array}{l}\text { Challenges / } \\
\text { advantages }\end{array}$ \\
\hline $\begin{array}{l}\text { Government } \\
\text { publications }\end{array}$ & $\begin{array}{l}\text { Statistical abstracts / } \\
\text { statistical year books } \\
\text { Economic Surveys } \\
\text { Development plans / } \\
\text { Poverty reduction } \\
\text { strategies } \\
\text { Annual budget speeches } \\
\text { Annual budget } \\
\text { statements } \\
\text { Audit reports } \\
\text { Other ad hoc studies }\end{array}$ & $\begin{array}{l}\text { Macroeconomic, } \\
\text { fiscal, labour, } \\
\text { human } \\
\text { development }\end{array}$ & $\begin{array}{l}\text { National statistical } \\
\text { websites (varies by } \\
\text { country) } \\
\text { Ministry of Finance or } \\
\text { Audit office websites } \\
\text { National or university } \\
\text { libraries } \\
\text { Libraries in Europe and } \\
\text { North America, e.g. } \\
\text { British Library, Senate } \\
\text { House Library }\end{array}$ & $\begin{array}{l}\text { Hard to physically } \\
\text { locate, often patchy } \\
\text { coverage, and } \\
\text { requires knowledge } \\
\text { of country document } \\
\text { names and } \\
\text { publication history }\end{array}$ \\
\hline
\end{tabular}

\footnotetext{
${ }^{10}$ Note that because the focus is on sources that allow analysis of change over time, it does not cover the many recent innovations in socioeconomic measurement, using for instance satellite imagery to measure light intensity or housing quality, or new measures of values and opinions, such as the Afrobarometer.
} 


\begin{tabular}{|c|c|c|c|c|}
\hline $\begin{array}{l}\text { World Bank } \\
\text { publications }\end{array}$ & $\begin{array}{l}\text { Public expenditure } \\
\text { reviews } \\
\text { Economic Memoranda } \\
\text { Sector studies }\end{array}$ & $\begin{array}{l}\text { Macroeconomic, } \\
\text { fiscal, labour, } \\
\text { business climate, } \\
\text { sectoral }\end{array}$ & Online & $\begin{array}{l}\text { Central repository, } \\
\text { but most reports are } \\
\text { standalone and data } \\
\text { coverage is not } \\
\text { systematic across } \\
\text { reports }\end{array}$ \\
\hline IMF publications & $\begin{array}{l}\text { Recent Economic } \\
\text { Developments } \\
\text { Article IV / staff } \\
\text { monitoring reports } \\
\text { Statistical appendix }\end{array}$ & $\begin{array}{l}\text { Macroeconomic, } \\
\text { fiscal, monetary } \\
\text { and finance, labour }\end{array}$ & Online & $\begin{array}{l}\text { Central repository } \\
\text { and standardized } \\
\text { reports, and } \\
\text { comparatively } \\
\text { consistent data } \\
\text { reporting }\end{array}$ \\
\hline ILO publications & $\begin{array}{l}\text { Labour force survey } \\
\text { reports } \\
\text { Manpower survey } \\
\text { reports } \\
\text { Ad hoc studies on } \\
\text { labour-related topics } \\
\end{array}$ & Labour & Online & $\begin{array}{l}\text { Central repository but } \\
\text { mostly standalone } \\
\text { reports; search tool } \\
\text { requires some } \\
\text { familiarity with } \\
\text { sources }\end{array}$ \\
\hline $\begin{array}{l}\text { Microdata } \\
\text { repositories }\end{array}$ & $\begin{array}{l}\text { Household budget } \\
\text { surveys } \\
\text { Demographic and health } \\
\text { surveys } \\
\text { Labour force surveys } \\
\text { Enterprise surveys } \\
\text { Ad hoc }\end{array}$ & $\begin{array}{l}\text { Household-level } \\
\text { economic, } \\
\text { educational and } \\
\text { health variables }\end{array}$ & Online & $\begin{array}{l}\text { Only a subset of } \\
\text { surveys are released } \\
\text { to researchers in } \\
\text { microdata form. } \\
\text { Requires time } \\
\text { investment to make } \\
\text { use of 'raw' data }\end{array}$ \\
\hline $\begin{array}{l}\text { Census data } \\
\text { repositories }\end{array}$ & $\begin{array}{l}\text { Housing and population } \\
\text { censuses }\end{array}$ & $\begin{array}{l}\text { Household-level } \\
\text { economic and } \\
\text { educational } \\
\text { variables }\end{array}$ & Online & $\begin{array}{l}\text { Focused solely on } \\
\text { censuses, but } \\
\text { centralized, } \\
\text { comparable data } \\
\text { across countries and } \\
\text { years }\end{array}$ \\
\hline $\begin{array}{l}\text { Other United } \\
\text { Nations agencies } \\
\text { - e.g. FAO, } \\
\text { UNESCO, } \\
\text { UNIDO }\end{array}$ & Various, mostly ad hoc. & $\begin{array}{l}\text { Agriculture, } \\
\text { industry, } \\
\text { education, etc. }\end{array}$ & Online & $\begin{array}{l}\text { Mixed degree to } \\
\text { which agencies have } \\
\text { created searchable } \\
\text { online archives; } \\
\text { requires } \\
\text { familiarization with } \\
\text { each agency's } \\
\text { platform }\end{array}$ \\
\hline Bilateral donors & Ad hoc studies & Mixed & Online & \\
\hline
\end{tabular}

Government statistical publications are a first point of call. While no longer published in colonial blue books, the break in government statistical collection in Africa after independence is not always as sharp as it is made out to be (see also Jerven, p.35). In the first decade of independence, many countries continued to collect much of the same data as during the colonial era and often increased the production of national accounts and data on industrial output and prices, collated in new statistical series.

Beyond national archives and libraries on the African continent, many libraries in the former colonial metropolises hold a considerable collection of these postcolonial statistical bulletins, abstracts and reports. In London for instance, the British Library, Senate House Library, LSE and SOAS shelve a large collection of statistical publications from Anglophone Africa, although the coverage declines in the 1970's. The library aggregation search tool, the Library Hub, provides an easy way of searching 
across the catalogues of most of the research libraries in the United Kingdom. ${ }^{11}$ The British Library has put together useful guides to the content of its African government publication collections, which can help to furnish the user with publication titles, although these sometimes do change over time. ${ }^{12}$ World Bank reports (discussed below) can also be a good guide to country publications as they often review and discus the data production in a given sector.

A few countries - notably Kenya - has digitized its annual statistical abstracts dating back to the late 1950's and make them available from its statistical bureau website. This publication summarizes statistics from across sectors and will often provide references to the underlying surveys or reports on which it builds. For more recent decades, many countries publish at least some budget documents and audit reports on the respective ministry of finance or audit office websites, and often a smattering of publications on the statistical bureau websites. These websites are worth browsing carefully. The headers and folders used on the main agency page are often poor guides to their actual content, and a review of all main subfolders sometimes throws up more material than expected.

However, these country-specific sources can be time-consuming to collect, particularly for studies that rely on large country samples, as they require familiarity with each country's statistical output and nomenclature. Usefully, many of the basic statistical series produced by these national bureaus were republished in contemporary IMF and World Bank reports. In the past decade these two institutions have digitized a large swath of their document archives. Consequently, troves of statistical data are buried in hundreds of thousands of PDFs, now available for download from their respective websites. These repositories contain far greater coverage and more detail than the series available from the World Development Indicators and other curated databases. Neither institution advertises these databases with great fanfare. Their websites are designed to showcase current projects and initiatives, and search algorithms will lead researchers first and foremost to country pages, recent reports or showcased projects, rather than the document archives.

For economic history research, the World Bank 'documents and reports' archive is particularly useful, and contains material dating back to the late 1950 's. ${ }^{13}$ This repository contains intermediate, or semiprocessed goods; rather than final research papers, it contains the country-level descriptive reports that form part of the World Bank's general monitoring or provide the basis for lending decisions and programme design. Some familiarity with the World Bank production of reports and studies is helpful for navigating this trove of material. The World Bank's repository for instance, allows searches by type of publication. By limiting the search to 'publications or research' or 'economic and sector work' - former World Bank speak for background studies and country-level research products - it is

\footnotetext{
${ }^{11}$ https://discover.libraryhub.jisc.ac.uk/

${ }^{12}$ https://www.bl.uk/collection-guides/african-government-publications

${ }^{13}$ http://documents.worldbank.org/curated/en/home
} 
possible to filter out the myriad project reports and legal documents that otherwise clog the search results and then manually review all search results for relevant material. Many of these reports, particularly the World Bank's flagship research products such as public expenditure reviews and country economic memoranda, contain statistical appendices that compile data from the national accounts and government accounts. They often collect broadly the same sets of statistics in each new study. Depending on the focus of the study, many also offer sector-specific statistics, be it on agriculture, education or infrastructure.

The IMF's archive catalogue search function is less advanced and less user friendly than that of the World Bank. ${ }^{14}$ For purposes of harvesting economic data - be it on government revenue and expenditure, GDP, inflation or banking - an effective approach is to collect issues of a given type of IMF publication for a given country by searching for the series title or key words in the title search bar, such as 'Article IV,' 'Recent Economic Developments,' or 'Statistical Appendix'. For economic data, the IMF's 'Recent Economic Developments' reports are particularly useful. They were produced regularly on a country by country basis between the 1960's and 1980's, using a roughly standardized template. IMF staff reports on the Article IV consultations and monitoring programmes, where IMF staff report on general developments and economic risks and assess programmatic performance, are likewise valuable and often the only source of consistent basic economic data for the more recent period. Compilation of statistics is also often available in sporadic releases of country statistical appendices, often appended to 'selected issues' papers (thus commonly titled 'selected issues and statistical appendix'). Many of these publications follow a standard format and collect much the same information year in and year out. The IMF reports also have the added advantage that they provide a running commentary on economic developments in the given country and a contemporary assessment of the reliability of the available statistics. One practical difficulty is that a given report often comes with separately archived supplements, appendices and notifications carrying similar document titles and filed as separate entries, thus the user may need to sift through multiple records to locate the main file.

Another useful institutional repository is provided by the International Labour Organization (ILO), which makes much of its archive of reports and studies available online through the portal labordoc, ${ }^{15}$ including country studies on labour laws, labour relations, manpower, labour statistics and more, dating back to the 1960's. Many are ad hoc studies, rather than standardized and regular reports, and therefore the most useful starting point may simply be to sift through everything published on a given country. Within these reports, data from recent surveys are often republished in tabular form in appendices.

\footnotetext{
${ }^{14} \mathrm{https}: / /$ archivescatalog.imf.org/search/simple

${ }^{15}$ https://labordoc.ilo.org
} 
A further valuable source of statistics are household and enterprise surveys. The International Household Survey Network, an umbrella organisation for international organisations and donors that support survey programmes in developing countries, provides a large catalogue of surveys from across the world, organised by country and year. ${ }^{16}$ Some records simply document past surveys for which microdata is not publicly available, in other cases this site provides links to the data supplier, which usually allow researchers access to the microdata after registering with the relevant authority or organisation.

Household surveys from the pre-1980's period are few and of mixed quality, but starting in the late 1980s the pace of survey production has accelerated, presumably due to falling cost of computing power that made them cheaper to analyse and administer. Many household budget surveys, demographic and health surveys and censuses are today available to academic researchers in microdata form, which vastly increases the use to which the data can be put and have been used extensively as cross-sectional measures of contemporary variation in living standards. While these sources are primarily designed to measure demographic trends and living standards, they also offer an important alternative source of information on access to public services, infrastructure and employment. Because they are based on the testimonies of randomly sampled households rather than records of government departments, they provide a means of cross-checking the veracity of some administrative sources, be it on public sector employment, wages or access to services and infrastructure.

Within the household survey landscape, housing and population censuses deserve special mention. The Minnesota Population Center's Integrated Public Use Microdata Series (IPUMS) project has constructed a central repository for census microdata from around the world. Usually a $10 \%$ sample of the census is available for download. Over 70 African censuses have been made available to date from 27 countries. Most are from the 1990's and 2000's, but in a few cases the censuses date back to the 1970's (Benin, Cameroon, Lesotho and Liberia) or 1960s (Kenya and Togo). Many contain variables on educational attainment and place of birth, in addition to basic demographics. This allows spatial studies at far more granular level than most alternative sources.

Depending on the research area, other UN agencies and institutes offer some historical sources and statistical repositories, for instance on agriculture (FAO) and industry and production (UNIDO). However, the breadth of the online archive and usability of the search engines vary significantly by agency. In addition, some bilateral donors provide archives or studies and reports commissioned by

\footnotetext{
${ }^{16}$ http://catalog.ihsn.org/index.php/catalog; the same catalogue is also available through many of the IHSN partner websites.
} 
them. USAID's Development Experience Clearinghouse, ${ }^{17}$ for instance, contains reports dating back to the 1960 's.

Many of these sources have been used extensively by scholars in disciplines other than economic history. Surveys are commonly designed with policy research questions in mind, but the growing availability of household microdata from Africa has also been put to unconventional uses, with the DHS, for instance, spurring a literature on the political economy of ethnicity (Franck and Rainer, 2012), and class (Shimles and Ncube, 2015). Historical data on road expenditure in Kenya was used to study relationships between democracy and ethnic patronage (Burgess et al.2015).

Some research has also made use of these sources with the explicit aim of challenging or enriching debates in economic history. With a focus on Kenya, Tanzania and Uganda, for instance, Simson (2018) showed that many features of a postcolonial state that have been invoked to explain why the fiscal crises of the 1980's proved so enduring, such as the excessive size of the civil service and government budget, look different when analysed across time. Drawing primarily on World Bank and IMF reports, this work showed that public spending declined soon after the crises of the 1970's set in. With the exception of debt service payments, domestic recurrent spending and later staff numbers came under considerable pressure. This lends greater support to theories that emphasise external rather than internal drivers of the crises. Albers and Suesse (2016), in a paper on tax intensity in Africa over the course of a century, found that the legacies of colonial taxation structures in Africa faded after independence and did not prove enduring. Bossuroy and Cogneau (2013) used household budget surveys from five African countries to provide the first measures of net intergenerational occupational mobility in the postcolonial, showing important country variations in farm to non-farm mobility that may have colonial roots. While not strictly an economic history paper, Alesina et al. (2019) have used the IPUMS International census data to map educational mobility across the continent and shed light on the drivers of the rate of educational mobility, including historical ones.

Although these sources of postcolonial economic statistics may require a greater time investment to collect and interpret than some of the colonial era sources, they offer opportunities to enrich key debates in African economic history about institutional persistence or its corollary. They can shed light on how state structures and policy altered after independence and the causes and consequences of the economic crises and structural adjustment reforms of the 1980's and 1990's. By using economic history methods and lenses to explain changes in the more recent past, they can also make African economic history more relevant to African policymakers and commentators today.

\footnotetext{
${ }^{17}$ https://dec.usaid.gov/dec/content/search.aspx
} 


\section{References}

Acemoglu, D., Johnson, S. and Robinson, J. A., 2002. Reversal of fortune: Geography and institutions in the making of the modern world income distribution. The Quarterly Journal of Economics, 117(4), pp.1231-1294.

Akyeampong, E. 2017. African Socialism; or the Search for an Indigenous Model of Economic Development, African Economic History Network Working Paper \#36

Akyeampong, E., 2018. African socialism; or, the search for an indigenous model of economic development? Economic History of Developing Regions, 33(1), pp.69-87.

Akyeampong, E., Bates, R.H., Nunn, N. and Robinson, J. eds., 2014. Africa's development in historical perspective. Cambridge: Cambridge University Press.

Albers, T. and Suesse, M. 2015. Colonial Fiscal Institutions in Africa: How they persisted, when they changed, and why, Manuscript presented at the AEHN meeting in Wageningen.

Alesina, A., Hohmann, S., Michalopoulos, S. and Papaioannou, E., 2019. Intergenerational Mobility in Africa, Working Paper No. 25534, National Bureau of Economic Research.

Andersson, J. 2015. Fiscal Capacity and State Formation in Francophone West Africa, 1850-2010, African Economic History Network Working Paper \#22

Andersson, J., 2017. Long-term dynamics of the state in francophone West Africa: Fiscal capacity pathways 1850-2010. Economic History of Developing Regions, 32(1), pp.37-70.

Andersson, J. 2018. Tax Stabilisation, Trade and Political Transitions in Francophone West Africa over 120 Years, African Economic History Network Working Paper \#41

Austin, G., 2008. The 'reversal of fortune' thesis and the compression of history: perspectives from African and comparative economic history. Journal of International Development: The Journal of the Development Studies Association, 20(8), pp.996-1027.

Austin, G. 2015. Is Africa too late for 'late development'? Gerschenkron south of the Sahara, African Economic History Network Working Paper \#23

Austin, G. and Broadberry, S., 2014. Introduction: The renaissance of African economic history. Economic History Review, 67(4), pp.893-906.

Burgess, R., Jedwab, R., Miguel, E., Morjaria, A. and Padró i Miquel, G., 2015. The value of democracy: evidence from road building in Kenya. American Economic Review, 105(6), pp.1817-51.

Brivati, B. (1996). 'Introduction,' in Brivati, B.; Buxton, J. and Seldon, A. (eds.). The Contemporary History Handbook (1st ed.). Manchester: Manchester University Press.

Cogneau, D. and Dupraz, Y., 2014. Questionable inference on the power of pre-colonial institutions in Africa. Paris School of Economics Working Paper N. 2014-25.

Cogneau, D. and Dupraz, Y., 2015. Institutions historiques et développement économique en Afrique. Histoire mesure, 30(1), pp.103-134.

Cogneau, D., Dupraz, Y. and Mesplé-Somps, S., 2015. Public Finances in Colonial West Africa: British and French compared. In XVIIth World Economic History Congress Working Paper. 
Cogneau, D. and Moradi, A. 2012. Borders that Divide: Education and Religion in Ghana and Togo since Colonial Times, African Economic History Network Working Paper \#4

Cogneau, D. and Moradi, A., 2014. Borders that divide: Education and religion in Ghana and Togo since colonial times. The Journal of Economic History, 74(3), pp.694-729.

Devarajan, S., 2013. Africa's statistical tragedy. Review of Income and Wealth, 59, pp.S9-S15.

Federico, G., 2017. 'The second cliometric revolution and the future of economic history' Keynote speech, OWL Seminar, London 2017 (January).

von Fintel, D. and Fourie, J. 2019. The Great Divergence in South Africa: Population and Wealth Dynamics over two Centuries, African Economic History Network Working Paper \#47.

Von Fintel, D. and Fourie, J. 2019. The great divergence in South Africa: Population and wealth dynamics over two centuries. Journal of Comparative Economics. In press.

Fourie, J., 2016. The data revolution in African economic history. Journal of Interdisciplinary History, 47(2), pp.193-212.

Fourie, J. 2019. Who Writes African Economic History? Economic History of Developing Regions, 34(2), pp.111-131.

Fourie, J. and Gardner, L., 2014. The internationalization of economic history: A puzzle. Economic History of Developing Regions, 29(1), pp.1-14.

Fourie, J. and Obikili, N., 2019. Decolonizing with data: The cliometric turn in African economic history, Stellenbosch Working Paper Series No. WP02/2019

Franck, R. and Rainer, I., 2012. Does the leader's ethnicity matter? Ethnic favoritism, education, and health in sub-Saharan Africa. American Political Science Review, 106(2), pp.294-325.

Frankema, E. and Jerven, M. 2013. Writing History Backwards or Sideways: Towards a Consensus on African Population, 1850-present, African Economic History Network Working Paper \#10

Frankema, E. and Jerven, M., 2014. Writing history backwards or sideways: towards a consensus on A frican population, 1850-2010. The Economic History Review, 67(4), pp.907-931.

Frankema, E. and Van Waijenburg, M., XXX. Structural impediments to African growth? New evidence from real wages in British Africa, 1880-1965, Working Paper, University of Wageningen

Frankema, E. and Van Waijenburg, M., 2012. Structural impediments to African growth? New evidence from real wages in British Africa, 1880-1965. The Journal of Economic History, 72(4), pp.895-926.

Frankema, E. and Van Waijenburg, M., 2014. Metropolitan blueprints of colonial taxation? lessons from fiscal capacity building in british and french africa, c. 1880-1940. The Journal of African History, 55(3), pp.371-400.

Frederick, K. 2018. A Comparative Analysis of East and West African Cotton Cloth Production from the Early Modern to the Post-colonial Era, African Economic History Network Working Paper \#37

Gardner, L., 2012. Taxing colonial Africa: the political economy of British imperialism. Oxford University Press.

Hopkins, A. G. 2009. The new economic history of Africa. The Journal of African History, 50(2), 155-177.

Hopkins, A.G., 2019. Fifty years of African economic history. Economic History of Developing Regions, 34(1), pp.1-15.

Jerven, M., 2013. Comparability of GDP estimates in Sub-Saharan Africa: The effect of Revisions in Sources and Methods Since Structural Adjustment. Review of Income and Wealth, 59, pp.S16-S36. 
Jerven, M., 2013. Poor numbers: how we are misled by African development statistics and what to do about it. Cornell University Press.

Jerven, M., 2015. Africa: Why economists get it wrong. London: Zed Books.

Jerven, M., Austin, G., Green, E., Ucke, C., Frankema, E., Fourie, J., Inikori, J.E., Moradi, A. and Hillbom, E., 2012. Moving forward in African economic history: Bridging the gap between methods and sources. African Economic History Network.

Juif, D. 2019. Mining, Paternalism and the Spread of Education in the Congo since 1920, African Economic History Network Working Paper \#46.

Kelly M. (2019). The standard errors of persistence. CEPR discussion paper 13783.

Lamoreaux, N. (2015) 'The Future of Economic History Must Be Interdisciplinary', Journal of Economic History, 75(4): 1251-7.

Meier zu Selhausen, F., van Leeuwen, M. H. D. and Weisdorf, J. L., 2017. Social Mobility among Christian Africans: Evidence from Anglican Marriage Registers in Uganda, 1895-2011, African Economic History Network Working Paper \#32

Michalopoulos, S. and Papaioannou, E., 2013. Pre-colonial ethnic institutions and contemporary African development. Econometrica, 81(1), pp.113-152.

Moradi, A., Austin, G. and Baten, J. 2013. Heights and Development in a Cash-Crop Colony: Living Standards in Ghana, 1870-1980, African Economic History Network Working Paper \#7

Nunn, N., 2008. The long-term effects of Africa's slave trades. The Quarterly Journal of Economics, 123(1), pp.139-176.

Nunn, N. and Wantchekon, L., 2011. The slave trade and the origins of mistrust in Africa. American Economic Review, 101(7), pp.3221-52.

Shimeles, A. and Ncube, M., 2015. The making of the middle-class in Africa: Evidence from DHS data. The Journal of Development Studies, 51(2), pp.178-193.

Simson, R. 2016. Patronage or Meritocracy? Public sector employment in postcolonial Kenya, Tanzania and Uganda, African Economic History Network Working Paper \#26

Simson, R., 2019, forthcoming. Africa's clientelist budget policies revisited: public expenditure and employment in Kenya, Tanzania and Uganda, 1960-2010. The Economic History Review. 